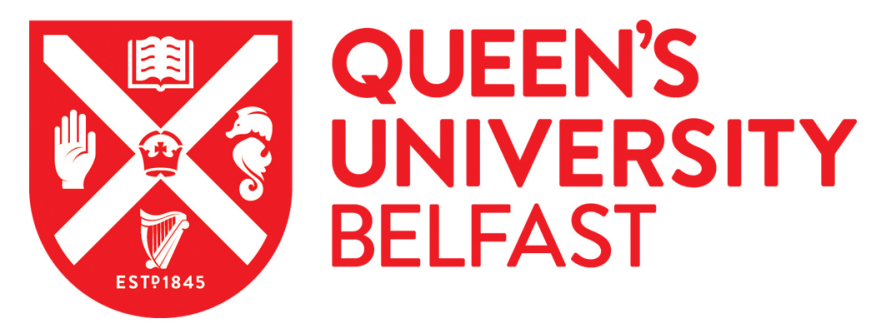

\title{
Constructions of Roles in Studio Teaching and Learning
}

Belluigi, D. Z. (2016). Constructions of Roles in Studio Teaching and Learning. The International Journal of Art \& Design Education, 35(1), 21-35. https://doi.org/10.1111/jade.12042

\section{Published in:}

The International Journal of Art \& Design Education

\section{Document Version:}

Peer reviewed version

Queen's University Belfast - Research Portal:

Link to publication record in Queen's University Belfast Research Portal

Publisher rights

(c) 2016 The Author. iJADE \& NSEAD/John Wiley \& Sons Ltd. This work is made available online in accordance with the publisher's policies. Please refer to any applicable terms of use of the publisher.

\section{General rights}

Copyright for the publications made accessible via the Queen's University Belfast Research Portal is retained by the author(s) and / or other copyright owners and it is a condition of accessing these publications that users recognise and abide by the legal requirements associated with these rights.

Take down policy

The Research Portal is Queen's institutional repository that provides access to Queen's research output. Every effort has been made to ensure that content in the Research Portal does not infringe any person's rights, or applicable UK laws. If you discover content in the Research Portal that you believe breaches copyright or violates any law, please contact openaccess@qub.ac.uk. 


\title{
Constructions of roles in studio teaching and learning
}

\begin{abstract}
Various constructions of supervisors and students emerge from education literature on art, design and architecture studio pedagogy. Constructions of the supervisor within the studio and during assessment are considered, with a discussion of the threads which underpin them. This is followed by a discussion of some of the current dominant constructions of the student, and possible effects of these roles and relationships on his/her engagement with learning. As many of these constructions may be inherited or unconscious, a concern for the agency of those involved to rupture, subvert, rescript or resist such constructions motivates this research, while acknowledging that this may be limited by structural and cultural contexts.
\end{abstract}

\section{Keywords}

Discourse; construction; assessment; studio; agency

\section{Introduction}

Even though there may be a lack of educational reference frames for teaching in the studio (Edström 2008), what has been recognised in published literature and studies in fine art, design and architecture education is that the relationships between student and supervisor within the studio has an effect on student learning (Blair 2006; Belluigi 2007; Webster 2004; 2005). What this points to is the importance of the supervisor-student relationship which, because of the intimate 'work-in-progress' nature of their interaction, involves student effort in adjusting to the supervisor's reactions to his/her artwork. Austerltiz and Aravot's (2006) research has shown that with each 'singular emotional episode' the student learns about the supervisor and the student him/herself, and so after repeated exposure these singular events can develop into 'emotional stances', which influence the student's approach to learning. Such stances may be productive, reproductive or counter-productive depending on how power dynamics, affective concerns and discourses position and manage those involved. So 
whilst it might be claimed from the position of those teaching that 'most of what happens in the studio is entirely unknown to us: it is uncognised, unanalaysed, unthought' (Elkins 2001, p.108), many studies point to the awareness that students have of the complex influences which the supervisor may exert (Dineen et al. 2005; Webster 2004). I would argue that there is value to having those within teaching and learning be cognisant of how relationships are not just experienced, but rather constrained or enabled by how roles are constructed, and thus open these to reimagining and resistance.

\section{Discursive positioning}

This paper is underpinned by socio-cultural conceptions of learning as student engagement, which acknowledge that learning is affected both by the context of study and by the type of experiences students have. As such there is a focus on the conditions - the cultures, contexts and circumstances which may enhance, constrain or maintain student involvement. Discourses both shape and are shaped by such conditions, and as such prove a fertile point of analysis into teaching and learning. A close reading of Foucault's (1979; 1980)works indicate that he refutes over-deterministic readings of the power of discourse to manipulate, control or transform individuals. Rather than seeing people and their actions solely as constructed by discourse, the understanding of discourse and subjectivity that informs this paper is that discourses do not determine identity but rather provide possibilities or conditions within which they may be resisted or negotiated. This is a sense of the human subject as a psychological subject (B. Davies \& Hare 1990) who is shaped and shapes him/herself through momentary but continuous identifications with discursive positions.

In this paper I propose that notions of the self as decentered and constituted within contextual discourses are useful for considering how the person choosing to teach or to study is constructed and made visible as a 'teacher' or a 'student' through the constraints and possibilities of the practices and pedagogic interactions of this community of practice. A number of studies by educationalist of studio teaching and learning have utilized such notions of how the self is constructed rather than discovered within structures such as education (Atkinson 1999; Reid \& Solomonides 2007; 2006; GoodingBrown 2000; Orr 2011). Such discursive formation of subject positions is known to happen at the 
level of the body, with the person often internalising and colluding with the constructions imposed upon them, and at times resisting them. Identity has been described as

the meeting point, the point of suture, between, on the one hand, the discourses and practices which attempt to 'interpellate', speak to us or hail us into place as the social subjects of particular discourses, and on the other hand, the processes which produce subjectivities, which construct us as subjects which can be 'spoken'. Identities are thus points of temporary attachment to the subject positions which discursive practices construct for us (Hall 2000, p.19).

Identities are not simply enacted. Having an understanding of what motivates individual's choices to adopt, resist or assume discursive positions is as important as identifying the discursive structures that construct such identities themselves. What is important in education is to recognise that teachers' conceptions of their roles have an impact on student learning (Prosser \& Trigwell 1998) and may undermine or support assessment (Blair 2007). Thus the supervisor's role in terms of student learning is more than just than enacted, but also perceived, constructed and experienced by themselves, their colleagues and the students.

Drawing from art education research, I look at such constructions of the student-supervisor relationships in undergraduate studio pedagogy, beginning with models of teaching which are currently explicitly or implicitly in use in the studio, many of which are seemingly in conflict with this sense of partnership and student autonomy: the master-apprentice relationship; the atelier method; the reflective practitioner, the analyst and patient; the luminal servant. Threads underlying these models are explored in an attempt to sketch the role of the supervisor, and the interplay with the role of assessor. The impact of such interplay and at times mis-fit on student engagement is considered, leading to a discussion on constructions of the student. 


\section{Constructions of the studio-supervisor}

\section{The master}

This master-apprentice model is perhaps the oldest, coming from the medieval workshop where an apprentice worked with a master while making the latter's art. Thus this mimetic model was originally conceived of as focusing on the master's practice, rather than the apprentice's artwork or process of learning. For Edström (2008), it is this particular focus that makes this model inappropriate for contemporary studio learning, as the student's practice and learning is espoused as the focus of the teacher's activity. Whilst the mimetic, reproductive nature of the process is now obsolete for contemporary education, the potential value within the processes of enculturation and epistemological access inherent within this tradition should perhaps not be overlooked. Cunliffe (2007) argues for a shift towards a mentor/apprenticeship relationship rather than the traditional master/ apprentice conception. This relationship acknowledges the process of enculturation by example that underpins both conceptions, but has a softer socio-cultural emphasis on the positive learning environment for the individual to flourish within the community of practice alongside a role model.

\section{The atelier coach}

In a study by Webster (2004) exploring architecture studio supervisors' conceptions of their role, the majority pointed to the atelier model of the expert as coach. The atelier method places teaching and learning within one-to-one 'studio conversations' between supervisor and student. The espoused theory of this model involves offering constructive criticism on ideas and proposals, and helping the students realize their ideas. A tradition arising from the French academy, the espoused theory is that in the atelier model, the student's artwork becomes the medium for the learning process, on which the creative processes, aesthetics and critique are focused. This focus on the students' rather than the master's work is evidence of the shift from the master as artist to the 'master' as teacher.

'Close personal relationships' are seen by some as an expected student-supervisor dynamic, due to the teacher acting as a coach while the student 'learns by doing' (Harwood 2007). These informal interactions are still seen by many as major advantage of the studio (Austerlitz \& Aravot 2006). 
However, questions as to the value of this method and the 'master's' influence extend back to the $19^{\text {th }}$ Century Romantic academies. As early as the 1980s, Swann (1986) famous called from the death of this model, which he termed 'sitting by Nellie'. He argued that the atelier method was not sustainable in the face of organisation pressures and educational requirements. Moreover, he questioned whether it was ever of value to the student's intellectual development(Elkins 2001, p.n.p.). In addition to concerns about the importance that this model may give to the student-supervisor relationship, another complication of the model has to do with the diversity of students. In her study, Webster (2004)found that supervisors felt the coach model could only be enacted for those students who were already fully acculturated and high-level.

\section{The reflective practitioner}

One of the ways of being within the studio supervisor models, is that of the reflective practitioner (Schön 1983). ‘Reflection-in-action’ occurs when supervisors respond through immediate observation and formative feedback to their students' work one-on-one in the studio (Hetland et al. 2007). For reflection-in-action to be properly engaged with requires 'sensitive, trusting and responsive teacherstudent relationships necessary to facilitate, continually respond to and adapt to what emerges from the process' (Usher et al. 1996, p.169). A critique of this model is that it creates a dependency on the master-apprenticeship dynamic (Usher et al. 1996). A critique of reflection-in-action is that it is most often accommodative and reactionary, thus requiring moments of reflection-outside-action to add a critical dimension. The critical distance of the portfolio and the 'critique' method of assessment (otherwise called 'jury', 'review', 'dialogue' etc), with the inclusion of other staff and peers, are potential spaces for reflection-outside-action.

\section{The critical friend}

In my own writing (Belluigi 2007; 2010), I have argued for a shift towards the studio supervisor's role as one of critical friend, taking into consideration the roles of reflection-in-action (Schön 1983) within the studio and assessment twinned with reflection-outside-action (Usher et al. 1996) in the 'critiques'. Studies have shown that students often intentionally use such interactions for alternative options and 
interpretations of their work, and to situate themselves in the professional community of practice (Dineen et al. 2005).This would involve constructive feedback framed by negotiated feedback indicators which are partially informed by the students intentionality. Here teachers forego their own desires or intentions imposed or projected on the student for willingness to facilitate the student's achievement of his/her intention. This model would require an openness to a relationship of partnership by both partiies, and is informed by conceptualiations of caring relationships within recent feminist psychology as being 'mutually engaging and rewarding' (Tom, 1997:6). However, if the sense of coaching is found by teachers to be only useful for high level learners, then the sense of collegiality of the 'critical friend' model requires a perceived equality in the minds of the supervisors that is perhaps only possible at a post-graduate level.

\section{The liminal servant}

Another student-centred approach is the 'liminal servant' (McLaren 1993). Here the supervisor aims to assist the student's construction of knowledge via critically reflective dialogue that involves both cognitive and social dimensions of learning, i.e. scaffolding the students' engagement with the underlying structures of the discipline. Some of the characteristics of this construction would be enthusiastic engagement by the tutor; the openness of both parties to each other's requirements; twoway challenging and task-orientated communication; a sense of empathy about the frustrations and process of practice; and a sense of shared management of the learning process (Webster 2004). In one study, architecture students construction of their 'ideal' studio supervisor was most similar to this model (Webster 2004). Whilst most of the participating supervisors in that study espoused this model, the findings from her observations and student data indicated that this was not the case in practice. However, as with the atelier method, in the few instances where tutors supported student learning as 'liminal servants' this was when students were either high-level learners or have already been enculturated within the discipline. 


\section{The analyst}

The relationship between studio supervisor and student has similar characterics to the relationship of analyst and patient, as explored by Ochsner's (2000) study of the design studio. The studio as a space of creative and shared play shares similar phenomena with therapy. Such environments may evoke previous relationships and events in the student's life which s/he may manifest as unconsciously projected roles onto the supervisor. Informed by psychotherapy, he suggests that the supervisor should practice the 'capacity to hold and contain', i.e. foster a sense of trust through an environment free of retribution, so that the student is willing to accept the risks and ambiguities of engaging in 'play' in the studio, and that 'with this sense of security, the student should be able to explore widely and freely; without it, explorations will be constrained, and true insight into design will not be likely to occur' (Ochsner 2000, p.195). Ochsner also writes on the values of the awareness and use of the psychoanalytic concepts of mirroring, transference and counter-transference for the studio supervisor.

Assuming such instances of projection as underlying human interaction, Ochsner argues that the value of this psychoanalytic understanding is that it asks of the supervisor to self-analyse whether the relationship is 'a growth-promoting symbiosis that is helping the student move to a position of being independently able to engage in the creative play' of studio practice. A critical reading of this proposed model may be that it creates the illusion of and focus on a modernist sense of self, and further empowers the teacher, in a relationship already out of balance, by reinforcing patronizing relationships to some extent depend on confession and exposure and at worst pathologise the student. The value of Ochsner's discussion is that it creates awareness about the psychological implications, and the fine lines which may be tread, within the student-supervisor relationships.

\section{Emerging threads in terms of the role of the supervisor in the studio}

Whilst the different models discussed above can be read as influenced by the different systems from within studio teaching and learning, what is of most relevance is how the studio supervisor's role is understood from within these constructions. The master-apprenticeship method is perhaps the one most clearly assertive of the notion of the supervisor as an 'ideal' example from the professional 
community for the student-apprentice to follow or mimic; the atelier method to some extent removes learning from the pressures of the professional world, with the supervisor in an 'expert' teaching role to provide instruction around the processes of learning to make art; the critical friend model sees the supervisor's role as advising prospective artists about the possibilities and problematics of his/her intentions and learning processes; the luminal servant acts as a facilitator of the student's epistemological access to this academic discipline; while the analyst model sees the supervisor's role as deepening the students understandings of his/her self and insights into the learning process. There are inherent differences between these models, which cannot be overlooked. However, I would like to pick the strands that go beyond this, and from them weave a sense of what the contemporary studio supervisors' roles are seen to be in the studio setting.

One of the strongest threads seems to the teacher's role in modeling, on both an ontological and epistemological level, the problematic, processes and possibilities of being (an artist/ architect/ designer etc) and making artefacts in the contemporary community of practice. Such modeling creates opportunities for embodied learning within the studio, where students do not simply watch and mimic the supervisor at work, but become acquainted with ways of thinking, feeling and doing in the practice. An aspect of this is how (and how successfully) the supervisor enacts his/her identity, and to what extent this implicit or explicit modeling enculturates the student to the various ways of being and knowledge constructions of the professional and academic communities. This is further complicated by what the student internalizes, adapts or resists.

Operating and inducting the student into the domain, a related aspect of the supervisor's role is to draw connections, comparisons and distinctions between student work, current artefacts in professional practice and historical references (Hetland et al. 2007). In such ways, the supervisor mediates between the student and the professional community of practice.

Another aspect of the studio supervisor's role is to create a productive balance between the student's interests and learning; that of his/her peers as a learning community; the demands of academia and the interests of the contemporary professional community. In a sense supervisors can be seen to have dual 
curricula in the studio - a curriculum for the whole class with conceptual objectives; and an individualised curriculum for each student (Hetland et al. 2007).

Schön (1983) identifies the studio processes of telling and listening, and demonstrating and imitating as central to the supervisor-student relationship. These are dependent primarily on the ability of the instructor to create an environment of 'shared play' in which these shared activities can take place (Ochsner 2000). The supervisor's role is perhaps most important in terms of how s/he enables the conditions for creativity (Belluigi 2010). The affective dimension of the studio space may hinge on the studio supervisors' approach to teaching and learning, which may or may not be aligned with assessment practices, as I explore in the next section.

\section{Role conflict: The supervisor as assessor in the Critique}

Many argue that the assessment of work produced in the studio, and the learning that occurs in the studio, are two phenomena of teaching and learning that should be seen as separate (Dineen et al. 2005). This is based on the understanding that summative assessment is made from an 'outsider view'. However studio interactions involve the supervisor in the formative process, so that studio supervisors enact interpretation both within the studio and assessments. Within the studio, this would involve asking questions about the student's work to understand what is intended, presenting opportunities and interpretations that the student has yet not considered. In that context the aim would be to aid the student's enhanced understanding and expand his/ her own work, and only at times becoming more critical to indicate problems or difficulties (Ochsner 2000). 'Critiques' may tend more towards the latter. However, the supervisor has the potential to act as a 'discourse leader' within assessments, suspending his/her judgement as 'expert' basing discussion on a sense of equality, connected to but not dictated by the intentionality of the student (Mitchell 1996).

Whilst some supervisors may find the two roles of supervisor and assessor as different and distinct, the fluidity and overlap between these roles are not lost on students, who may find such separation disingenuous. Research conducted from students' perspectives of their 'best' assessments has highlighted the affective role of the supervisor in 'critiques'. Students indicate a desire to have the 
supervisor demonstrate 'care' for their students, foster an environment of 'good will'; to some extents protect the students from humiliation; make it possible for the student to feel encouraged enough after the 'critique' to return to their work (Barrett 2000). Of interest is the contrast between constructs of supervisors and assessors.

Assessors at 'critiques' have been characterized as 'liminal servants', 'entertainers' or 'hegemonic overlords' (McLaren 1993). In her study of the architecture review, Webster (2004) describes how the 'entertainer' can be positioned as concerned only with the culture of the professional community of practice through sharing anecdotes and making historical references, to the exclusion of student interaction and interest. The assessor-critic of the hegemonic overlord model is characterized as a 'power-wielding egocentric, eager for personal display and personal gratification, and intent on the coercion of student towards their personal notion of professional habitus' (Webster 2006, pp.291292). The manner in which this model is experienced by the students seems to differ in relation to their own level of acculturation, self-identity and learning, i.e. those that would be considered 'strong' in these areas perceived the 'hegemonic overlord' assessor as coercive; those considered 'weak' characterised the interaction as humiliating and bullying; while some of the latter took a strategic approach by adopting the assessors’ instructions (Webster 2004)

Research has shown that transformative pedagogic outcomes may be distorted and in some cases thwarted by assessment as 'ritualistic practices' which objectify and cement that power differential between the assessor as 'critic' and student as pedagogised other (Webster 2006, p.289). The confrontational nature of such assessments can negatively impact on the quality of learning taking place, where the student focus shifts from reflecting on their learning to 'defending' themselves, their choices and actions (Blair 2007). Supervisors may be concerned with how assessment within the 'critique' adds the element of judgement and critique to the relationship, which may inhibit the intended creative, supportive nature of the supervisor-student relationship (Hickman 2007). Students too may not associate the assesment experience with supportive learning environments (Black \& Wiliam 1998). Thus there is a perceived tension often from both parties between the studio supervisor's roles of support and criticism. 


\section{The impact of role conflict on student engagement}

Assessment in particular plays a strong role in how identities are constructed, and this is perhaps a reason why assessment in studio learning has received attention. From Foucault's (1979) to Butler's (1993) work, assessment in particular has been recognised as utilising discursive formations to position the subject as object or 'pedagogised other' (Atkinson 2006), positioning which may be experienced by those involved as alienating (Mann 2001). Examination makes the individual visible by objectifying and individualising him/her; the confessional creates conversations between a speaker and an 'other' who listens, judges and has the power to forgive but requires the confession in the first place.

Of the whole assessment process, research indicates that feedback holds the most potential to affect future learning and student achievement (Black \& Wiliam 1998; Blair 2006). However, the ways in which individuals are positioned within supervisor-student constructions, between the studio and the 'critique', may bring the efficacy of feedback into jeopardy (Blair 2006; Belluigi 2007). This is because how students receive feedback, and therefore the learning value of such pedagogic encounters, is affected by their perceptions of self, and their sense of identity as 'professionals' within the community (Blair 2007). Discursive and interpretative frameworks utilised by the supervisor within the studio and assessment impact on the students' reception of feedback and the impact on their learning. This can result in 'the level of response shifting to a self/ego level in which the learners' energies go into reconciling the mark with their view of themselves as learners' (Stobart 2006). In addition, because in these disciplines the personal response is valued highly (Hickman 2007), and because the student is so influenced by the supervisor's attentions, affective considerations of how feedback is given and received requires deliberation. Blair's (2006; 2007) research revealed that factors such as the power dynamic between teacher/student (Devas 2004) and stress factors (Pope 2005) impact on the intended benefits of the feedback. Because 'the self' is contingent on events (Sartre 1962) and dependant on others (Winnicott 1971), being is a situation where one's self is not validated in relationships and contexts may lead to a loss of 'self', agency or desire (Mann 2001). When such estrangement from the student's creative and autonomous self occurs, it may be replaced 
by a compliant self that is to some extent bereft of the capacity for creativity. Such a dynamic is worsened when one party (the teacher) objectifies all their judgments and the other party (the student) subjectifies all theirs (Falchikov \& Boud 2007).

\section{Constructions of the student}

As important as constructions of the supervisor and assessor, are those of the student. In this section I explore some of the constructions that have emerged from literature on studio learning, which are heavily influenced by notions from professional communities of practice and traditions of adult education.

\section{The Apprentice}

One of the dominant constructions of the student is that of an apprentice to a master, which extends from the early informal education of the medieval workshop guild and is still lauded in many current circles through Schön's teacher-centred paradigm. A hierarchical sense of 'earning your stripes' and 'knowing your place' led the student of the workshop to become journeyman and then master, just as students now must progress along a degree or diploma structure, in the hopes of being considered 'master' (thus postgraduate qualifications of that name). In this way the supervisor and student are subject to forces of construction by the adult education context of studio practice, which Ball et al. (2002, pp.52-53) refer to as the 'social classification of self and institution'(Orr 2011, p.42).

This mimetic teaching tradition has resulted in a marked absence of student voice and in some cases a lack of concern for students' aspirations (Harwood 2007, p.315). The politics and power differentials of the 'critique' in particular involve elements of the 'deference' an inferior subordinate displays to acknowledge the formal status of his/her superior. An effective means for acculturating students, the apprenticeship model has been critiqued for it reproductive accent, where students are expected to disregard their pre-existing habitus in favour of assuming that of their supervisor(Webster 2005, p.280). 


\section{The emotional / intuitive artist-student}

The characterization of the student, particularly within fine art practice, as more intuitive, emotional and sensitive than the mainstream, may find its roots in notions of the Romantic artist genius and humanist notions of the artist as the ideal of fulfilled selfhood. Fendrich (2005) cautions that even though myths of the Romantic artist have been subverted with postmodernism, many of today's artists allow themselves to carry the residue of this myth, uncritically believing they are morally superior and more emotionally sensitive than non-artists, and that they are 'pitted against a cold and corrupt society'. Addison (2007) writes of how in British education, expressivist notions of self-affirmation and multiculturalism are linked to artmaking subjects, where artworks embody traces of concretized subjectivity rather than aspects of cultural identity. Underlying this is a modernist sense of the self as fixed and immutable, with ability being innate or unequally bestowed by 'god-given talents'. In practice, this is sharply exclusionary of those not constructed as 'talented', but in theory the artist is transcendentally free and beyond contextual influence. Romantic myths of the autonomous, authentic, artist-genius can be seen to unwittingly silence the artist and in turn the student.

\section{The collaborator}

Postmodernism allows for a 'co-constructivist' concept interconnecting students with each other and their supervisor(s) with various different 'knowledges', experiences and communities. This sense of the 'artist as collaborator' (Hardy 2006, p.12) is a notion within the critical adult learning tradition (Usher \& Johnston 1997). The educator is recognized as part of the Culture Industry, and so while acting as commentator and interpreter it is the student who supposedly has more significance and power.

\section{The reflexive practitioner}

While Schon's (1983) model of the reflective practitioner is highly lauded, it is with reflexivity rather than reflectivity that this model acquires a postmodern sting in its tail. Such reflexivity is essential to contemporary artmaking in particular: artists are to extend their socially, politically and historically reflexive explorations to the physicality of the work and vice versa. The fluidity between formal learning spaces and everyday life, theory and practice, attempts to push the student beyond the 
dictates of the established discipline. This model constructs the student as actively involved in questioning, pondering and critiquing both him/ herself and the structures in which s/he operates, so as to determine his/her own discursive position rather than unconsciously assume or comply with those imposed. In this way, the model of student as reflexive practitioner is very much influenced by a contemporary conception of the artist (Dallow 2003). In many ways this is a tall order, as the student is constructed as able to identify, navigate and even resist discursive forces of which even their supervisors may not be consciously aware. Moreover, questions as to how one can see one's positioning, within the discourse which one is enmeshed, abound.

Some of these ideas can be traced to political pressure in the past and present. Linked to the 'reflexive practitioner', the current emphasis on the artist as 'practical intellectual' (Dallow 2003, p.53) perhaps began with the attempt to raise the status of art education as a discipline within the academy (Preziosi 1989; Schiralli 2002), and the current attempt to have arts practice seen as research may be informed by similar political aims. While the idea of the artist as involved and responsive to his/her community and context may have postmodern and/ or critical impetus, it could also be influenced by neo-liberalist pressure to make curricula more responsive and accountable in terms of the agenda of globalization.

What each of the constructions discussed above evidence are models imposed upon students, a phenomenon common across education. As authors of curricula and other pedagogical structures and methods in higher education, academics often default back to that which they learnt or experienced, reproducing normative values from their perspective 'which accords with the author's self-perception and cultural experience' (Webb 1996, p.27). The 'ideal' student then becomes the person who finds out how to demonstrate that learning most valued by the teacher, while the rest often learn in superficial ways without deep understanding (Elton 2001). This sense of the supervisor creating an image of him/herself may be problematic (Haggis 2003), as the focus and impetus remains teacher- or curriculum-centred rather than concerned with or representative of the goals or motivations of the diversity of students. The articulation of such constructions in this paper is in the hopes of creating openings for their resistance or reimagining, as I allude to in the following section. 


\section{Problematising this representation of the constructions of student-}

\section{supervisor roles}

In this paper, I have outlined some of the constructions of supervisors and students in the studio that have emerged from art education literature. However I am aware that I may be accused of unwittingly reproducing these structures as reified, if I do not give due consideration to the ways in which individuals have agency to choose whether to adopt or resist such constructions. While this applies as much to supervisors as to students, the critical accent of my research orientation requires that I give due consideration to the possibilities for student agency and motivation in terms of their navigating these constructions.

Such considerations of agency necessitate a brief discussion of notions of autonomy in adult education (Usher \& Johnston 1997). Perhaps the most significant characteristic of adult learning is the goal of autonomy - the goal of self-awareness, empowerment, and exercising choice in relation to needs. Most adult learning traditions conceive of autonomy as 'government of self by the self, a freedom from dependence, a situation where one is influenced and controlled only by a source from within oneself' (Usher et al. 1996, p.93). This creates a binary separation between the self and the social. In the critical tradition, which attempts to remove the oppressions of history and social context from learning, the social is positioned as a force or a thing from outside of the self. What is perceived as preventing autonomy is that which is outside or 'other' to the self - i.e. that which is different to the self. However, in postmodern notions the social is seen as a condition of being a person. What this conception allows for is the possibility of the person, whether student or lecturer, to act as both meaning-maker and meaning-taker in terms of discourses.

For instance, student conceptions of learning have been seen to influence the approach that they will take when engaging with the subject (Marton \& Saljo 1984), and how they rationalize the cost of taking that stance. Experiences of alienation and engagement also affect the choices students make in terms of their learning (Mann 2001). Intrinsic and extrinsic motivation of students in response to contexts at a point in time, are factors which play into how they learn and construct themselves. To 
what extent and form the student approaches the transformation of his/her identity, whether towards the professional identity or that of student, is another consideration. A useful distinction is that between discourse or narrative, as a product, and the act of narration, which is more of an embodied social practice that intentional agents do routinely (Day Sclater 2003, p.317). A narrative is created by the student which positions the values, beliefs and expectations they have of themselves in relation to their perceptions of the academic and professional community of practice (Austerlitz \& Aravot 2006). Pertinent to this section is how sentiments about and the potential intimacy of the supervisor-student relationship influence and direct such experiences and narrative assertions. The dynamic and complex nature of this relationship is seen to contribute to the 'emotional knowledge' a student develops and integrates with his/ her own 'emotional biography’ during his/her studies. In fact, a level of emotional adaption may be an unintended outcome of studio learning (Austerlitz \& Aravot 2006).

While some argue that in the studio a 'student's ability to choose is based on knowing what he/she wants to achieve' (Dineen et al. 2005, p.37) many others have argued that such autonomy in education is an illusion. Rather the person adopts certain approaches either to collude with or resist structures which construct him/her. Webster (2005, p.279) writes of how students in her study learned to present both their work and themselves through experience rather than being taught the rules, with mastery involving strategic 'playing' but not necessarily believing in 'the game'. For instance, through the repeated experiences of 'critiques', students devise and develop strategies that they believe might guarantee them the best outcome, even if for some this is simply for self-preservation (Webster 2006; Belluigi 2007). Rather than accepting the discursive formations and non-discursive practices of 'critiques', and the supervisor's embodiment of authority and dominant habitus as legitimate, in many cases students are seen to strategically perform compliance (Webster 2006; Belluigi 2007). This may create the illusion that students can construct or narrate their own discursive position unhindered. However individual agency may be bounded by and limited within the umbrella values and norms of disciplinary teaching and learning, professional practice, and conceptual and material constraints (Webster 2006). 


\section{Conclusion}

In this paper, constructions of the roles of those in art, design and architecture studio education and the possible impact on student engagement have been explored. Rather than seeing the person as 'subject' to such discourses, the acknowledgement of agency in this paper is to potentially shift the focus of power away from the constraining or determining nature of such constructions. GoodingBrown (2000, pp.48-49) points to the critically reflexive potential this understanding has for the person and how engaging role-players in such thinking may have 'important implications and consequences for art education and education in general'. The reflexive potential of articulating and questioning such discursive positioning for the supervisor, is that it creates openings for a person to break the typical pattern - of educators approaching teaching and learning relationships by mimicking the way they were taught or the way they learnt, in a cycle where they create images of themselves (Bourdieu 1977). Through critical reflections of such constructions in one’s own pedagogical practice, teachers may question their positioning and narration of their own identity and habitus, and in turn hopefully aid their students in their narrative negotiation, construction and reimaging of their role as students and practitioners.

\section{Reference list}

Addison, N. (2007) Identity Politics and the queering of art education: Inclusion and the confessional route to salvation. Journal of Art \& Design Education, Vol. 26, No. 1, pp.10-20.

Atkinson, D. (1999) A critical reading of the national curriculum for art in the light of contemporary theories of subjectivity. Journal of Art \& Design Education, Vol. 18, No. 1, pp.107-113.

Atkinson, D. (2006) Assessment in educational practice: Forming pedagogised identities in the art curriculum, in T. Hardy [Ed] Art education in a postmodern world: Collected Essays. Bristol, U.K: Intellect Books.

Austerlitz, N. \& Aravot, I. (2006) The emotional structure of the student-tutor relationship in the design studio, in Proceedings of the 3rd CLTAD International Conference. Enhancing Curricula: contributing to the future, meeting the challenges of the 21st century in the disciplines of art, design and communication. London: CLTAD, pp. 79-94.

Ball, S., Davies, J., Madiv, M. \& Reay, D. $\{2002\}$ 'Classification' and 'judgement': social class and 'cognitive structures' of choice in higher education, British Journal of Sociology of Education, Vol. 223, No. 1, pp.51-72. 
Barrett, T. (2000) Studio critiques of student art: As they are, as they could be with mentoring, Theory into Practice, Vol. 39, No. 1, pp.29-35.

Belluigi, D.Z., 2010. Creating the conditions for creativity: looking at assessment in fine art studio practice, in C. Nygaard, C. Holtham, \& N. Courtney [Eds] Teaching Creativity - Creativity in Teaching. Libri Press.

Belluigi, D.Z. (2007) Excavating the 'critique': An investigation into disjunctions between the espoused and the practiced within a fine art studio practice curriculum. Master of Education thesis. Grahamstown: Rhodes University.

Black, P. \& William, D. (1998) Assessment and classroom learning, Assessment in Education, Vol. 5, No. 1, pp.7-72.

Blair, B. (2006) An examination of the learning value of formative feedback to students on undergraduate design courses - through the process of the studio critique. Doctor of Philosophy. London: London University Institute of Education.

Blair, B. (2007) At the end of a huge crit in the summer, it was 'crap'. I'd worked really hard but all she said was 'fine' and I was gutted, Art, Design \& Communication in Higher Education, Vol. 5, No. 2, pp.83-95.

Bourdieu, P. (1977) Reproduction in education, society and culture, Newbury Park, California: Sage.

Butler, J. (1993) Bodies that matter: On the discursive limits of 'sex', London: Routledge.

Cunliffe, L. (2007) Towards a more complex description of the role of assessment as a practice for nurturing strategic intelligence in art education, in T. Rayment [Ed] The problem of assessment in art and design. Bristol: Intellect Books.

Dallow, P. (2003) Representing creativeness: practice- based approaches to research in creative arts, Art, Design \& Communication in Higher Education, Vol. 2, No. 1/2, pp.49-66.

Davies, B. \& Hare, R. (1990) Positioning: The discursive construction of selves, Journal for the Theory of Social Behaviour, Vol. 20, pp.43-63.

Devas, A. (2004) Reflection as confession: discipline and docility in/on the student body, Art, Design \& Communication in Higher Education, Vol. 3, No. 1, pp.33-46.

Dineen, R., Samuel, E. \& Livesey, K. (2005) The promotion of creativity in learners: theory and practice, Art, Design \& Communication in Higher Education, Vol. 4, No 3, pp.155-172.

Edström, A.-M. (2008) Art students making use of studio conversations, Art, Design \& Communication in Higher Education, Vol. 7, No. 1, pp.31-44.

Elkins, J. (2001) Why art cannot be taught: A handbook for art students, Urbana: University of Illinois Press.

Elton, L. (2001) Research and teaching: conditions for a positive link, Teaching in Higher Education, Vol. 6, pp.43-56. 
Falchikov, N. \& Boud, D. (2007) Assessment and emotion. The Impact of being assessed, in D. Boud \& N. Falchikov [Eds] Rethinking assessment in higher education Learning for the longer term. New York: Routledge, pp. 144-155.

Fendrich, L. (2005) A portrait of the artist as a young mess, Chronicle of Hlgher Education, Vol. 51, Vol 39, pp.B6-B8.

Foucault, M. (1979). Discipline and punish: The Birth of the Prison, Harmondsworth, Middlesex: Penguin.

Foucault, M. (1980). Power/knowledge: Selected interviews and other writings,1972-1977 C. Gordon, ed., Brighton, Sussex: Harvester Press.

Gooding-Brown, J. (2000) Conversations about art: A disruptive model of interpretation, Studies in Art Education, Vol. 42, No. 1, pp.36-50.

Haggis, T. (2003). Constructing images of ourselves? A critical investigation into 'approaches to learning' research in higher education, British Education Research Journal, Vol. 29, No. 1, pp.89-104.

Hall, S., 2000. Who needs 'identity'? in P. Du Gay, P. Evans, \& Redman P [eds] Identity: A reader. London: Sage.

Hardy, T. (2006). Domain poisoning: The redundancy of current models of assessment through art, International Journal of Art \& Design Education, Vol. 25, No. 3, pp.268-274.

Harwood, E. (2007) Artists in the academy: curriculum and instruction, in L. Bresler [Ed] International Handbook of Research in Arts Education, Dordrecht: Springer.

Hetland, L., Winner, E., Veenema, S. \& Sheridan, K. M. (2007) Studio thinking. The real benefits of visual arts education, New York: Teachers College Press.

Hickman, R. (2007) (In defence of) whippet-fancying and other vices: Re-evaluating assessment in art and design, in The problem of assessment in art and design. Bristol: Intellect Books.

Mann, S. (2001) Alternative perspectives on the student experience: alienation and engagement, Studies in Higher Education, Vol. 26, No. 1, pp.8-19.

Marton, F. \& Saljo, R. (1984) Approaches to learning, in D. Martin, D. Hounsell, \& N. Entwistle [Eds]. The experience of learning. Edinburgh: Scottish Academic Press.

McLaren, P. (1993) Schooling as a ritual performance: towards a political economy of educational symbols and gestures, London: Routledge.

Mitchell, S.E. (1996) Institutions, individuals and talk: The construction of idenity in fine art, International Journal of Art \& Design Education, Vol. 15, No. 2, pp.143 - 154.

Ochsner, J.K. (2000) Behind the mask: A psychoanalytic perspective on interaction in the design studio. Journal of Architectural Education, Vol 53, No. 4, pp.194-206.

Orr, S. (2011) 'Being an artist you kind of, I mean, you get used to excellence': Identity, values and fine art assessment practices. Journal of Art \& Design Education, Vol. 30, No. 1, pp.37-44. 
Pope, N. (2005) The impact of stress in self and peer assessment, Assessment \& Evaluation in Higher Education, Vol. 30, No. 1, pp.51-63.

Preziosi, D. (1989) Rethinking art history: Meditations on a coy science, New Haven, Conn: Yale University Press.

Prosser, M. \& Trigwell, K. (1998) Understanding learning and teaching: The experience in higher education, Philadelphia, Pa: Open University Press.

Reid, A. \& Solomonides, I. (2007) Design students' experience of engagement and creativity, Art, Design \& Communication in Higher Education, Vol. 6, No. 1, pp.27-39.

Sartre, J.-P. (1962) La Nausee, London: Hamish Hamilton.

Schiralli, M. (2002) Anxiety and uncertainty in aesthetic education, Journal of Aesthetic Education, Vol. 36, No. 2, pp.52-66.

Schön, D. A. (1983) The reflective practitioner: How professionals think in action, New York: Basic Books.

Day Sclater, S. (2003) What is the subject? Narrative Inquiry, Vol. 13, No. 2, pp.317-330.

Stobart, G. (2006) The validity of formative assessment, in J. Gardner [Ed] Assessment and Learning. London: Sage, pp. 133-146.

Swann, C. (1986) Nellie is dead, Art and Design Education, Vol. 1, No. 1, pp.18-20.

Usher, R., Bryant, I. \& Johnston, R. [Eds] (1996) Adult education and the postmodern challenge: Learning beyond the limits, New York: Routledge.

Usher, R. \& Johnston, R. (1997) Reconfiguring the other. Self and experience in adult education, in R. Usher, I. Bryant, \& R. Johnston [eds] Adult education and the postmodern challenge. Learning beyond the limits. London: Routledge.

Webb, G. (1996) Understanding Staff Development, Buckingham: Society for Research into Higher Education.

Webster, H. (2004) Facilitating reflective learning: Excavating the role of the design tutor, Journal of Art, Design and Communication in Higher Education, Vol. 2, No. 3, pp.101-111.

Webster, H. (2006) Power, freedom and resistance: Excavating the design jury, International Journal of Art \& Design Education, Vol. 25, No. 3, pp.286-296.

Webster, H. (2005) The architectural review, Arts and Humanities in Higher Education, Vol. 4, No. 3, pp.265-282.

Winnicott, D.W. (1971) Playing and Reality, London: Tavistock. 